
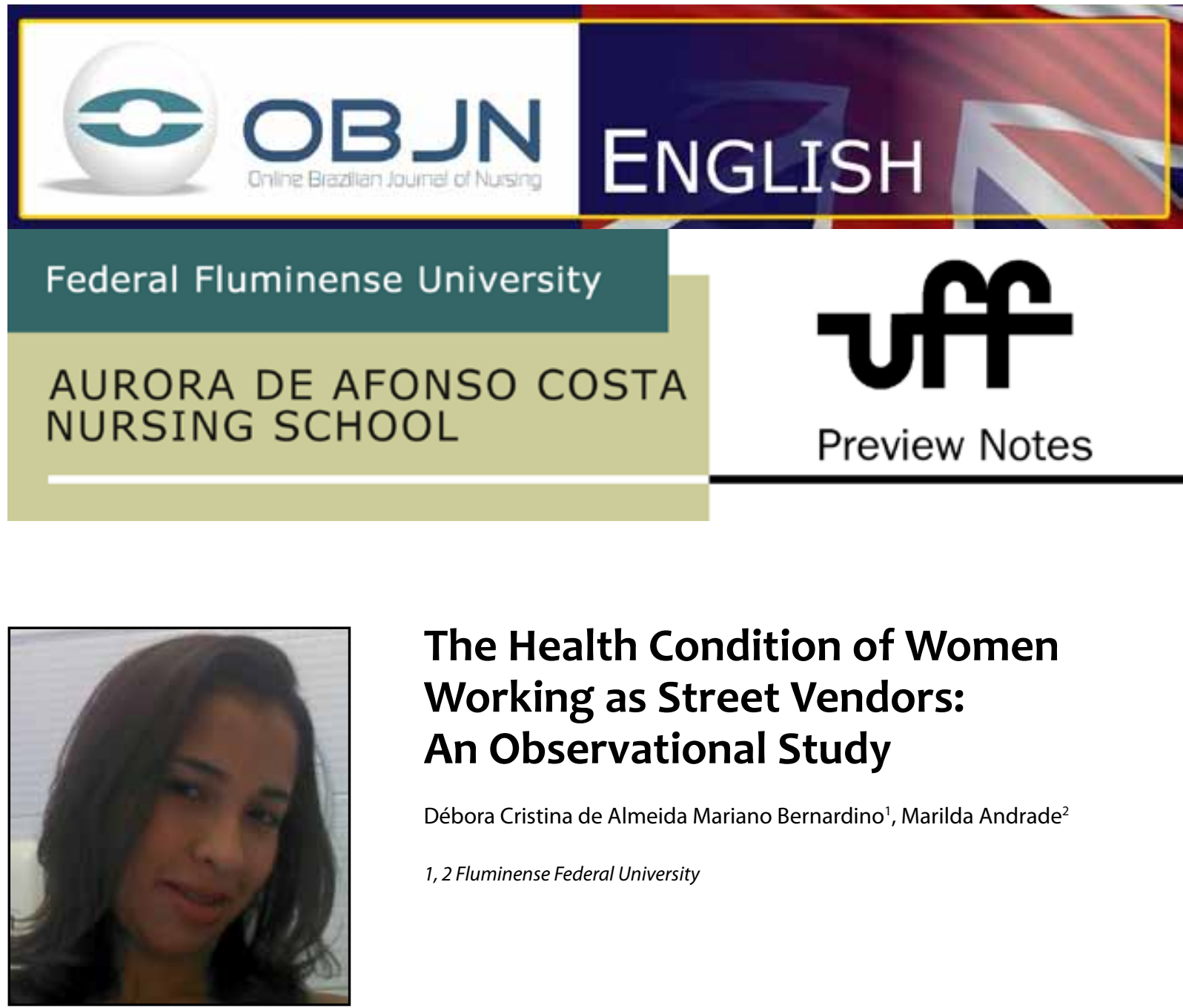

\title{
The Health Condition of Women Working as Street Vendors: An Observational Study
}

Débora Cristina de Almeida Mariano Bernardino', Marilda Andrade²

1, 2 Fluminense Federal University

\begin{abstract}
Aim: To describe the epidemiological profile and analyze the health conditions of female street vendors in the light of the social determinants of health. Method: Observational and on the streets of the city center of Rio de Janeiro. Data will be collected from June to July 2014 with mixed questionnaires. Subsequently these data will be entered in a database and imported into the Statistical Package for the Social Sciences (SPSS) software, where they will be analyzed by means of descriptive and analytical statistics. Expected Results: Scientific evidence that allows a diagnosis in terms of the health conditions and the needs of the female street vendor population. Implications for Health: To create better alternatives for integral health care, enabling increased quality of life for the individuals concerned.
\end{abstract}

Descriptors: Women Working; Health Status; Social Conditions. 


\section{PROBLEM SITUATION AND ITS SIGNIFICANCE}

The informal profession of street vendors is characterized by precarious conditions of work and life involving an extensive workload, very low pay and no guarantee of access to basic social and labor rights ${ }^{(1)}$. When such workers fall ill or are injured, they are not entitled to paid leave to deal with their health issues.

In the case of female participants in the labor market, this phenomenon did not mean the re-division of tasks between men and women. In many cases, women also keep house while caring for children, husband and housework, resulting in an overload of their physical and mental state.

In this context, it can be said that women, especially those included in the class of informal workers, are in a vulnerable situation, and may have worse health conditions as a result.

Based on the concept of social determinants of health (which provides social determinants in different layers, according to their level of coverage), we understand that the category in which the factors related to the conditions of life and work of the people are represented, presupposes that access to essential services such as health, education and work environment is an important factor in terms of a positive or negative influence on health ${ }^{(2)}$. Socially disadvantaged people have the disadvantages of exposure and vulnerability to health risks as a result of poor environmental conditions, exposure to often dangerous or stressful work situations, and less access to health services.

Given the above, it is understood that the female street vendors do not have their health needs entirely addressed due to their working conditions. It is necessary to know the reality of these women in relation to their health, life and work.
We hope to provide scientific evidence to create better alternatives for integral health care, enabling the improvement of life quality of the research under consideration.

\section{GUIDING QUESTIONS}

What are the health conditions of female street vendors from the perspective of casual work?

\begin{abstract}
AIMS
To describe the epidemiological profile of female street vendors;

To examine, in the light of the social determinants of health, the health conditions of these women from the perspective of casual work.
\end{abstract}

\section{ASSUMPTION}

Different social arrangements allow the possibility of having a prosperous life and enjoying good health to be distributed in different ways. These inequalities are observed in terms of the nature of employment, working conditions, physical characteristics and the quality of the environment in which people live. Depending on how each of these situations is presented, people become more or less vulnerable to disease ${ }^{(3)}$.

\section{METHOD}

This is an observational, cross-sectional and descriptive study. Inclusion criteria: female street vendors, aged over 18 years, who have carried on such activity for at least six months. Exclusion criteria: female workers who have a formal con- 
tract. Data will be collected in the period from June to July 2014 through questionnaires administered by the research team. The instrument was developed to incorporate mixed questions that include socioeconomic, health and working factors of female street vendors operating in the city center of Rio de Janeiro. We estimate that there is a population of 165 women who work casually in the study site. The sample calculation was performed from a knowledge of that number and with the help of the association of street vendors in the locality. We obtained a sample of 116 women through the Survey System program, version 10.5. The information collected will be entered into databases in the Microsoft Office Access program and it will be further analyzed by means of descriptive and analytical statistics, which is applied in the Statistical Package for the Social Sciences software (SPSS). The results will be presented in graphs and tables. Project approved by CEP-HUAP-UFF on 05/05/2014, opinion number 634975.

\section{REFERENCES}

1. Organización Internacional del Trabajo. En América Latina y el Caribe hay 127 millones trabajadores em la informalidad. Lima: Oficina Regional de la OIT para América Latina y el Caribe; 2013.4p.

2. Freitas LV, Joventino ES, Ximenes LB, Vieira NFC, Moreira RVO. Ética do cuidado de enfermagem diante da crise ambiental. Online braz j nurs [Internet]. 2012 November [Cited 2014 Apr 8]; 11 (3): 893-06. Available from:http://www.objnursing. uff.br/index.php/nursing/article/view/3833.
3. World Health Organization. Closing the gap in a generation: Health equity through action on the social determinants of health. Genebra: Commission on Social Determinants of Health; 2009. 247p.

\section{Project Data:}

Research of the academic Master's Postgraduate Program in Health Care Science EEAAC/FFU approved by CEP-HUAP-FFU on 05/05/2014, opinion number 634975

Advisor: Marilda Andrade

\begin{abstract}
All authors participated in the phases of this publication in one or more of the following steps, in According to the recommendations of the International Committee of Medical Journal Editors (ICMJE, 2013): (a) substantial involvement in the planning or preparation of the manuscript or in the collection, analysis or interpretation of data; (b) preparation of the manuscript or conducting critical revision of intellectual content; (c) approval of the versión submitted of this manuscript. All authors declare for the appropriate purposes that the responsibilities related to all aspects of the manuscript submitted to OBJN are yours. They ensure that issues related to the accuracy or integrity of any part of the article were properly investigated and resolved. Therefore, they exempt the OBJN of any participation whatsoever in any imbroglios concerning the content under consideration. All authors declare that they have no conflict of interest of financial or personal nature concerning this manuscript which may influence the writing and/or interpretation of the findings. This statement has been digitally signed by all authors as recommended by the ICMJE, whose model is available in http://www. objnursing.uff.br/normas/DUDE_eng_13-06-2013.pdf
\end{abstract}

Received: 08/29/2014
Revised: 09/30/2014
Approved: 09/30/2014 